ing up and letting down the cars containing fifty or sixty persons. At the end of the journey, completed in about fifteen minutes, at an ordinary walking speed, the car moves gently against a spring buffer, and is locked by a lever, without noise and without jolting the passengers. This interesting undertaking has been carried out at a cost of $£ 25,000$.

Mr. E. T. Dumple, writing in the Geological Bulletin of Texas, brings out a very interesting fact, and one which may shed some light upon the question of who were the builders of the shell-mounds of the coast regions of Texas. During the great storm of $\mathbf{I} 886$, which so nearly destroyed Sabine Pass, one of these shell-mounds, which was near a certain house on the river-bank, and the loeality of which was exactly known, was destroyed or carried away by the violence of the waves, and rebuilt nearly half a mile farther up stream than it formerly stood. It is therefore possible that these so-called Indian shellmounds, which are composed almost entirely of shells, with fragments of pottery, and sometimes a crumbling bone or two, were not built, as has been supposed, by Indian tribes who lived on shell-fish, but are entirely due to the action of the water ; and the presence of the Indian relics may be easily accounted for by remembering that these mounds are usually found in low ground, and, being high and dry, would naturally be selected as camping-places by the Indians in their hunting and fishing expeditions.

THE Vienna Correspondent of the Times records a curious relic of mediæval superstition in Austria. The Burgomaster of Zuraki, in Galicia, has just instituted a prosecution before the Criminal Court of Solotwina against a man named Jean Kowale-ink for having, "by his malicious sorceries and incantations, caused a hailstorm to devastate the fields of Zuraki on July 28." The damages occasioned by Kowalesink's uncanny power over the elements are laid at 6000 florins.

WE are glad to report that the Central Meteorological Observatory of Mexico has recommenced the publication of its Boletin Mensual, and in a more convenient form than before. This publication had been discontinued since December $1885^{\circ}$ It contains only a summary of the observations made at twenty or thirty stations, but the hope is expressed that the publication of the observations made at certain hours will be soon undertaken, and that the arrears will also be taken up, as the observations have been regularly made. The Bullet ins for the first five months of this year have been received.

The Report of the Meteorological Commission of the Cape of Good Hope, for the year 1887 , states that "the whole service has assumed a satisfactory character." Monthly and yearly summaries are given for twenty-nine stations, and for a large number of rainfall stations. As an inducement to observers, they are presented with the instruments with which they have made a series of satisfactory observations for a continuous period of five years. Summarized reports are sent daily to each coast port, and are there entered on a sketch-map for the benefit of the seafaring community. We observe, however, that in counting the number of wet days, a rainy day is taken as one upon which $0_{03}$ inch is recorded, whereas a quantity of 0.01 inch is the standard generally adopted in this country. The Commission express the hope that in time they may be able to issue storm warnings.

IN June last an interesting archæological discovery was made at Sonderby, on the west coast of Jutland. It consisted of about thirty urns of clay found in a moss at a depth of 3 feet. They occupied an area 4 feet wide and 10 feet long. Formerly there was a shallow lake here. Most of the vessels rested upon rough stones, but there was no trace of stone walls or roof; they varied from 2 to 8 inches in height. In most of them lay a hes and remnants of calcined bones, whilst the bottom was lined with some reed-like kind of grass. Some of the urn had lids, but others appear to have been placed in the earth open. Most of them were very simple in form, with smooth sides, but on some of the larger there were three knobs at the sides, and attempts at rough ornamentation. No metal or stone implement was found. In the same moss some huge oak trunks were also dug out.

A KIEL schoolmaster, Herr Spiedt, has excavated a so called "Viking mound" in the south of Jutland, close to the old frontier between Denmark and Prussia. In the eastern edge remains of a skeleton were found, and in the centre an oaken coffin, nailed with iron nails, containing the skeleton of a tall powerful man was found ; but no ornaments, weapons, or objects of any kind. The head pointed to the north-west. It was close to this mound that a Runic stone was found some years ago with the following inscription in runes: "King Svein set (raised) stone after (on the death of) Skarde, his homestead companion (probably meaning boy companion), who travelled west, and died in Hedeby." King Svein is the famous King Svein with the Double Beard, who ascended the thrones of England and Denmark on the death of his brother, King Canute, and his friend was one Skarde, who fought for him in this country. Hedeby was the ancient name for the town of Schleswig. It is believed that the skeleton is that of Skarde.

THE "Clasi-book of Elementary Chemistry," which Mr. W. W. Fisher, Aldriclian Demonstrator of Chemistry at Oxford, is preparing for the Clarendon Press Series, is nearly ready, and will be published in a few days.

THE additions to the Zoological Society's Gardens during the past week include a Small Hill Mynah (Gracula religiosa) from India, presented by $\mathrm{Mr}$. Alexander Robertson; a Common Sheldrake (Talorna vulpanser), British, presented by the Rev. II. H. Slater; an Avocet (Recurvirostra avocetta) from Holland, presented by $\mathrm{Mr}$. J. Hoogerduyn ; two Common Chameleons (Chanceleon vulgaris) from North Africa, presented by Mr. J. Alfred Lockwood; a Sea Anemone (Bolvara eques), a British Coral (Caryophyllaca, sp. inc.) from British Seas, presented by the Marine Biological Station, Plymouth, per Mr. G. C. Bourne; a Brown Bear (Lirsus arctos of), European, a Whitebacked Piping Crow (Gymnorthina leuconota) from Australia, twelve Mandarin Ducks ( $E$ Ex galericulata, 6 b , 6 o ) from China, deposited; two White-headed Parrots (Pionus senilis) from Mexico, four Oyster-catchers (Himantopus ostralegus) from Holland, purchased.

\section{ASTRONOMICAL PHENOMENA FOR THE WEEK 1888 SEPTEMBER 9-15.}

(FOR the reckoning of time the civil day, commencing at Greenwich mean midnight, counting the hours on to 24 , is here employed.)

\section{At Greenwich on September 9}

Sun rises, 5 h. $28 \mathrm{~m}$.; souths, I Ih. $57 \mathrm{~m}$. I $8 \mathrm{~s}$.; sets, I $8 \mathrm{~h} .26 \mathrm{~m}$. : right asc. on meridian, I Ih. I $2.9 \mathrm{~m}$.; decl. $5^{\circ} 4^{\prime} \mathrm{N}$. Sidereal Time at Sunset, $17 \mathrm{~h} .43 \mathrm{~m}$.

Moon (at First Quarter September I 2, 22h.) rises, 9h. 19m.; souths, I $4 \mathrm{~h} .55 \mathrm{~m}$. : sets, $20 \mathrm{~h}$. I $9 \mathrm{~m}$. : right asc. on meridian, I 4 h. II'Im. ; decl. $7^{\circ} 4^{\prime} \mathrm{S}$.

Planet. Rises. Scuths. Sets. Right asc. and declination meridian.

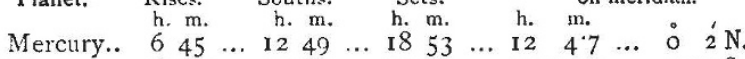

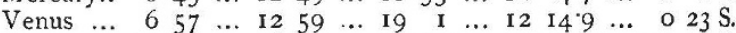
$\begin{array}{lllllllllllllllll}\text { Mars } & \ldots & 12 & 25 & \ldots & 16 & 30 & \ldots & 20 & 35 & \ldots & 15 & 46.7 & \ldots & 21 & 30 \mathrm{~S} .\end{array}$

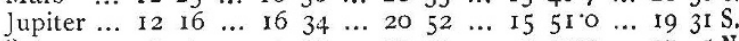

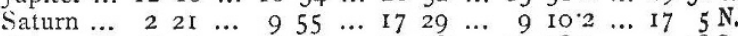

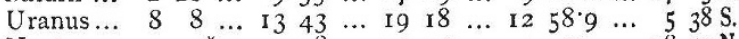

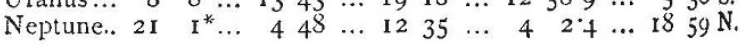
* Indicates that the rising is that of the preceding evening. 
Occultation of Star by the Moon (visible at Greenwich). Corresponding Sept. Star. Mag. Disap. Reap. $\begin{gathered}\text { angles from ver- } \\ \text { tex to right for }\end{gathered}$ I4 $\ldots \begin{array}{llllllllllllll} & 50 & \text { Sagittarii } & \ldots & 6 & \ldots & 22 & 5^{8} & \ldots & 0 & 4^{\dagger} & \ldots & 13 \hat{3} & 30 \AA\end{array}$ $\begin{array}{lllll}\begin{array}{c}\text { Sept. } \\ \text { II }\end{array} & \text { h. } & \text { Io } & \ldots & \text { Mars in conjunction with and } 6^{\circ} 7^{\prime} \text { south } \\ \text { of the Moon. } & \\ \text { II } & \ldots & \text { Io } & \ldots & \begin{array}{l}\text { Jupiter in conjunction with and } 3^{\circ} 55^{\prime} \text { south } \\ \text { of the Moon. }\end{array} \\ \text { II } & \ldots & \text { I4 } & \ldots & \begin{array}{c}\text { Mars in conjunction with and } 2^{\circ} \text { I } 2^{\prime} \text { south } \\ \text { of Jupiter. }\end{array}\end{array}$ Star. Variable Stars.

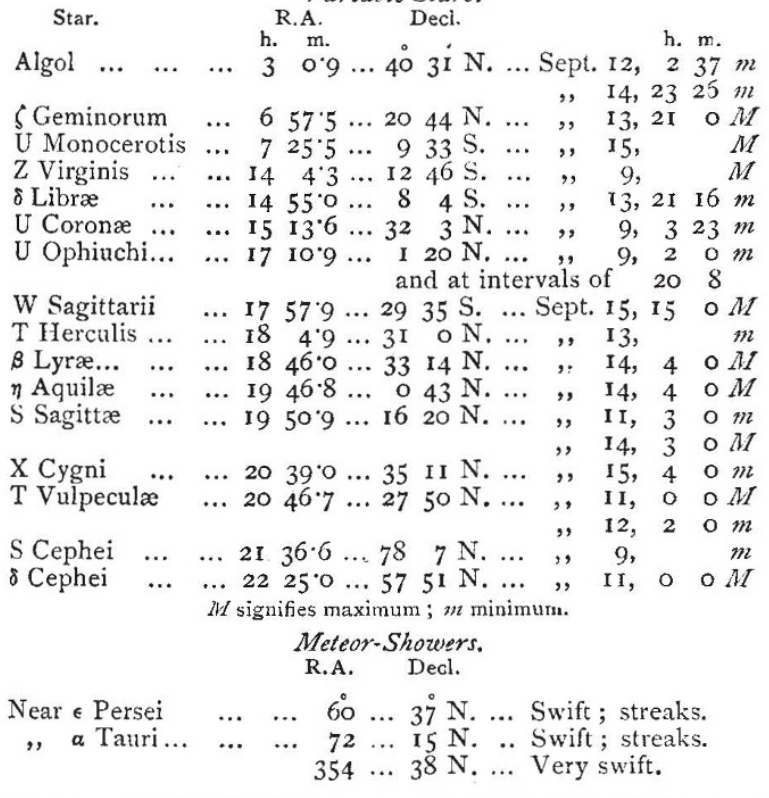

\section{GEOGRAPHICAL NOTES.}

THE elaborate Report of Mr. Bourne on his journey in SouthWestern China, which has recently been laid before Parliament, and to which we referred recently in connection with the ethnology of the non-Chinese races of this region, is of much geographical interest. Part of Mr. Bourne's journey was already traversed in the reverse direction by $\mathrm{Mr}$. A. R. Colquhoun, and described by him in his well-known work, "Across Chrysê." This observation applies to the route from Yunnan Fu, the capital of the province of that name, to Ssu-mao, and thence along the Tonquin frontier to Nanning on the West or Canton River. But Mr. Bourne traversed the region between Chung-king and Yunnan $\mathrm{Fu}$, which, however, as it lies on one of the high roads across China into Burma, is not unfamiliar to Western readers, and he also crossed diagonally the province of Kweichow--one of the least known provinces in the Chinese Empire-from Nanning in Kwangsi to Chung-king in Szechuen. Here he travelled along unbeaten tracks for many weeks; but even where travellers had been before-and at best Turopean travellers in Southern and South-IVestern China are extremely few and far between-his intimate knowledge of China and the Chinese, and the advantages which hi; official mission gave him, make his observations of exceptional value. He has also established the connection between the rivers of Northern Tonquin and the river system of Southern China. In regard to the seven route-sketches, which accompany the Report, of the different sections of the journey, Mr. Bourne explains that although the rate of travel (about 20 miles a day) precluded the idea of a running survey, it was easy to take notes of the prominent features of the country, as he walked nearly the whole way. These notes, which took the form of route-sketches, would, with an occasional position determined astronomically, have made it possible to give a much better idea of the country than the maps convey; but his record of astronomical observations, "which had cost him many a night's vigil," and portions of his route-sketches, were lost on the occasion of some riots in Chung-king, during which his house was attacked and looted. But the route-sketches of the last part of the journey were fortunately saved, and supply materials for a better map. There is likewise a vast number of careful meteorological observations. It is to be feared that the instinctive repulsion of the natural man to Blue-books, regardless of their $\mathrm{c}$ ntents, will prevent Mr. Bourne's Report from receiving the attention which it deserves. On a moderate computation, it would furnish materials for half a dozen works of travel such as those with which the public is made acquainted every year, which have their little day and cease to be. We have to go back to the Reports of Mr. Bourne's predecessors, Messrs. Baber and Hosie, to find any record of travel in China of equal interest and value.

Science reports that two important Expeditions left Rio de Janeiro in June for exploration and work in two of the leastknown parts of the Brazilian territory. The first, sent out by the Ministry of War, under the command of Captain Bellarmino Mendonça, is to open a road from the town of Guarapuaba, on the frontier of the settled portion of the province of Parana, to the confluence of the Rivers Parana and Iguassu, and to found a military colony at the latter point. A road is also to be opened along the Parana River from the mouth of the Iguassu to the navigable portion of the river above the Sete Quedas Fall, and from this point to Guarapuaba, viâ the valley of the Piquiri. The founding of a colony at the mouth of the Iguassu, where the Argentines are already establishing themselves, will, aside from its military importance, prove of great value in peopling the valley of the Upper Parana, which has been deserted since the time of the expulsion of the Jesuits. By means of the Lower Parana the colony will have free water communication with Buenos Ayres and other markets of the Argentine Republic, where two of its natural products, lumber and matte, will find a ready sale. This will give at once to the proposed colony a commercial importance far beyond that of a purely military station, and will doubtless lead to the rapid spread of population along the Upper Parana and its tributaries, with their hundreds of miles of navigable waters. The second Expedition, consisting of three military engineers, Capt. Lourenco Telles, and Lieuts. Miranda and Villeray, is sent out under the auspices of the Sociedade de Geographia de Rio de Janeiro, the expenses being borne by the Ministry of Agriculture. It is to proceed to Cuiaba in the province of Mato Grosso, pass by land to the head-waters of the Paranapinga, and descend that river and the Sao Manoel or Tres Barras to the Tapajos, returning to Rio de Janeiro viâ Para by the Tapajos and Amazonas. This explora. tion will thus be a valuable complement to that of the Tapajos by Chandless, as the Sao Manoel and Paranapinga are almost absolutely unknown.

THE current number of the Proceedings of the Royal Geographical Society opens with a paper by Commodore Markham on Hudson's Strait as a navigable channel, which is a condensed narrative of former voyages from the time of Sebastian Cabot, coupled with an account of the author's own observations. Commodore Markham comes to the conclusion that the Strait is perfectly navigable and free from ice in August and later in the season. Mr. Portman has a most interesting paper on the Little Andamans, while General Walker discusses the well-worn theme of the hydrography of South-Eastern Tibet. The Persian farsakh cannot be of much value as a precise measure of length, for in a very learned paper, which concludes the number, General Houtum.Schindler, of the Persian Telegraph Service, concludes that it is 3.915 miles, while in a footnote he gives the estimates of eight other authorities all differing from his own and from each other.

THE first number of vol. ix. of the Bulletin of the Paris Geographical Society is occupied with M. Maunoir's annual summary of the progress of geography and exploration during 1887. The work is as full and careful as these annual reviews by the same author usually are. The second number is wholly devoted to a record of the commemoration of the centenary of the death of Laperouse. The grand-nephew of the great navigator writes on his private life, and reproduces a number of his private and official letters. Lieutenant Courcel describes his voyage, and Vice-Admiral Paris recounts the history of the discovery of the remains of the expedition. The appendixes contain numerous papers relating to Laperouse and his companions, including a bibliography of works relating to the hero himself. 